\title{
Penilaian Dampak Bahaya Radiologis terhadap Radionuklida Natural di Pesisir Pulau Bengkalis
}

\author{
Murdahayu Makmur $^{1 *}$, Wahyu Retno Prihatiningsih ${ }^{1}$, Mohamad Nur Yahya ${ }^{1}$ \\ ${ }^{1}$ Marine Radioecology Group, Center for Technology of Radiation Safety and Metrology, \\ National Nuclear Energy Agency, Jakarta \\ *Corresponding author: mdhayu@batan.go.id
}

Info Artikel : Diterima Februari 2019; Disetujui September 2019 ; Publikasi Oktober 2019

\begin{abstract}
ABSTRAK
Latar belakang: Radionuklida natural ditemukan hampir di semua media lingkungan, dan di lingkungan laut terdeteksi cukup tinggi karena adanya proses erosi, pelapukan dan daur ulang mineral yang mengalami perpindahan melalui badan air. Radionuklida natural tersebut dapat berpindah ke berbagai media, termasuk ke manusia melalui rantai makanan.

Penelitian ini dilakukan untuk memberikan informasi dasar mengenai tingkat radio aktivitas di lingkungan perairan laut di Pesisir Pulau Bengkalis dan melakukan penilaian dampak bahaya radiologis melalui aktivitas ekuivalen radium $\left(\mathrm{Ra}_{\mathrm{eq}}\right)$ dan indeks bahaya eksternal $\left(\mathrm{H}_{\mathrm{ex}}\right)$ serta laju dosis eksternal dari radionuklida natural.

Metode: Metode deskriptif digunakan dalam penelitian ini dan metode pengambilan sample sedimen menggunakan metode purposive sampling. Sampel sedimen dikumpulkan dari 6 titik pengambilan sampel di pesisir Pulau Bengkalis, menggunakan sediment grab. Sampel kemudian dikeringkan dan dihomogenkan kemudian ditimbang sebanyak $1 \mathrm{~kg}$. Pengukuran aktivitas radionuklida dilakukan menggunakan spektrometri gama dengan waktu cacah selama 3 hari. Aktivitas ${ }^{226} \mathrm{Ra}$ ditentukan berdasarkan emisi sinar gamma ${ }^{214} \mathrm{~Pb}$ dan ${ }^{214} \mathrm{Bi}$. Aktivtias ${ }^{232} \mathrm{Th}$ ditentukan berdasarkan emisi ${ }^{212} \mathrm{~Pb}$ dan ${ }^{228} \mathrm{Ac}$ dan ${ }^{40} \mathrm{~K}$ ditentukan dari emisi pada 1461,8 $\mathrm{keV}$. Hasil analisis akan digunakan untuk menghitung dampak radiologis di lingkungan mengunakan ekuivalen aktivitas radium dan indeks bahaya eksternal.

Hasil: Aktivitas rata-rata berturut turut 56,$45 ; 31,34 ; 26,04 ; 33,19 ; 30,00$ dan $185,49 \mathrm{~Bq} / \mathrm{kg}$ untuk radionuklida ${ }^{226} \mathrm{Ra},{ }^{212} \mathrm{~Pb},{ }^{214} \mathrm{~Pb},{ }^{214} \mathrm{Bi},{ }^{228} \mathrm{Ac}$ dan ${ }^{40} \mathrm{~K}$. Aktivitas terukur mempunyai kisaran nilai yang berdekatan dengan pengukuran di beberapa negara. Penghitungan nilai aktivitas ekuivalen radium $\left(\mathrm{Ra}_{\mathrm{eq}}\right)$ berkisar dari 82,61 - $138 \mathrm{~Bq} / \mathrm{kg}$ dan tidak melebihi nilai yang ditetapkan oleh ICRP (1990) dan OECD (179) yaitu sebesar 370 $\mathrm{Bq} / \mathrm{kg}$. Nilai indeks bahaya eksternal $\left(\mathrm{H}_{\mathrm{ex}}\right)$ masih di bawah 1 , dengan nilai rata rata sebesar 0,31, danlaju dosis dari radionuklida natural sebesar 37,175 $\mathrm{nGy} / \mathrm{h}$.

Simpulan: Aktivitas radionuklida natural di pesisir Pulau Bengkalis mempunyai kisaran nilai yang berdekatan dengan pengukuran di beberapa Negara. Nilai aktivitas ekuivalen radium $\left(\mathrm{Ra}_{\mathrm{eq}}\right)$ Yang terukur tidak melebihi nilai yang ditetapkan oleh ICRP (1990) dan OECD (179).Nilai indeks bahaya eksternal $\left(\mathrm{H}_{\mathrm{ex}}\right)$ masih di bawah 1, dan laju dosis yang diserap lingkungan dari radionuklida natural masih di bawah nilai rata rata dunia. Dengan demikian, dapat disimpulkan bahwa parameter radiologis radionuklida natural dalam sedimen di pesisir Pulau Bengkalis berada dalam batas yang dapat diterima.
\end{abstract}

Kata Kunci : Bahaya radiologis; Radionuklida natural; sedimen; Spektrometer gama; Bengkalis

\section{ABSTRACT}

Title: Assessment of Radiological Hazard impact of Natural Radionuclides on the Bengkalis Island Coast Background: Natural radionuclides are found in almost all environmental media, and in the marine compartment have been detected relative high due to the process of erosion, weathering and recycling of minerals that come trough the water bodies. Radionuclides can move to various media, including to the humansthrough the food chain. This research was conducted to provide baseline information about the activity of radioactivity in the marine environment of the Bengkalis Island Coast and conduct radiological hazard 
impact assessments through equivalent radium $\left(R a_{e q}\right)$ and external hazard index $\left(H_{e x}\right)$ and external dose rates of natural radionuclides.

Methods: Descriptive methods were used in this study and the sediment sampling method used a purposive sampling method. Sediment samples were collected from 6 sampling points on the coast of Bengkalis Island, using sediment grab. The samples were then dried, homogenized and weighed $1 \mathrm{~kg}$. Measurement of radionuclide activity was carried out using gamma spectrometry with counting time for 3 days. The ${ }^{226} \mathrm{Ra}$ activity is determined based on ${ }^{214} \mathrm{~Pb}$ and ${ }^{214} \mathrm{Bi}$ gamma ray emissions. The ${ }^{232}$ Th activity was determined based on ${ }^{212} \mathrm{~Pb}$ and ${ }^{228} \mathrm{Ac}$ and ${ }^{40} \mathrm{~K}$ emissions determined from emissions at $1461.8 \mathrm{keV}$. The results of the analysis will be used to calculate the radiological impact in the environment using equivalent radium activity and external hazard index.

Results: The average activity are 56.45; 31.34; 26.04; 33.19; 30.00 and $185.49 \mathrm{~Bq} / \mathrm{kg}$ for radionuclides ${ }^{226} \mathrm{Ra}$, ${ }^{212} \mathrm{~Pb},{ }^{214} \mathrm{~Pb},{ }^{214} \mathrm{Bi},{ }^{228} \mathrm{Ac}$ and ${ }^{40} \mathrm{~K}$ respectively. The value of this activity comparable withthe activities in several countries. The calculation of radium equivalent activity $\left(R \mathrm{a}_{\text {eq }}\right)$ values ranges from $82.61-138 \mathrm{~Bq} / \mathrm{kg}$ and does not exceed the value $370 \mathrm{~Bq} / \mathrm{kg}$ by ICRP (1990) and OECD (179). The external hazard index value $\left(H_{e x}\right)$ is still below 1 , with an average value of 0.31 , and the dose rate of natural radionuclides is $37,175 \mathrm{nGy} / \mathrm{h}$.

Conclusion: Natural radionuclide activity on the coast of Bengkalis Island has a range of values adjacent to measurements in several countries. The measured value of radium ( $\left.R a_{e q}\right)$ activity does not exceed the value set by ICRP (1990) and OECD (179). The external hazard index value $\left(H_{e x}\right)$ is still below 1 , and the absorbed dose rate of natural radionuclides is still below the world average value. Thus, it can be concluded that the radiological parameters of natural radionuclides in sediments on the coast of Bengkalis Island are within acceptable limits.

Keywords: Radiological impact;Natural Radionuclide;sediment;Gamma Spectrometer; Bengkalis

\section{PENDAHULUAN}

Radionuklida dan dampaknya terhadap lingkungan merupakan objek utama dalam studi radioekologi ${ }^{1}$ baik radionuklida natural maupun radionuklida artificial atau buatan. Radionuklida dapat ditemukan di hampir semua media lingkungan seperti batu, tanah, sedimen, udara, tanaman, air permukaan (sungai, laguna dan laut) dan air tanah serta di manusia itu sendiri. Radionuklida di lingkungan laut juga terdeteksi cukup tinggi karena diperbanyak oleh adanya proses erosi, pelapukan dan daur ulang mineral dari batuan terestrial yang mengalami perpindahan melalui badan air. ${ }^{2}$

Radionuklida, baik alam (natural) maupun buatan (artificial) dapat berpindah dengan berbagai media di lingkungan, dan cepat atau lambat akan terdeposisi ke sedimen. ${ }^{3,4}$ Manusia terkena radiasi melalui gabungan radionuklida pada rantai makanan,sehinggaterjadi peningkatan tingkat paparan internal. Keberadaan radioaktivitas dalam air, tanah dan sedimen bertanggung jawab atas paparan eksternal ke manusia. Dengan demikian, penelitian tingkat konsentrasi, distribusi dan perilaku kimiadari radionuklida natural dan buatan manusia jugasangat penting untuk diketahui karena berhubungan dengan kesehatan manusia. $^{2}$

Penelitian mengenai radionuklida di perairan laut Indonesia, telah banyak dilakukan, terutama untuk radionuklida antropogenik. Monitoring lingkungan perairan laut pada tahun 2011 - 2013, telah dilakukan untuk mengidentifikasi ${ }^{137} \mathrm{Cs}$ dan ${ }^{134} \mathrm{Cs}$ pada sedimen, air laut dan biota untuk mengantisipasi dampak kecelakaan Fukushima. Monitoring ${ }^{137} \mathrm{Cs}$ juga dilakukan pada inlet Arus Lintas Indonesia pada tahun 2012, ${ }^{6}$ termasuk penelitian mengenai cesium dan plutonium di Teluk Jakarta yang dilakukan pada tahun $2016 .{ }^{7}$ Beberapa penelitian serupa yang dilakukan untuk mengetahui kondisi radionuklida di lingkungan juga dilakukan di berbagai daerah, seperti di daerah Gresik ${ }^{8}$, Belitung, dan daerah Bangka baik untuk sedimen ${ }^{10}$ maupun untuk air laut permukaan ${ }^{11}$.

Penelitian mengenai radionuklida natural juga sudah dilakukan sejak lama dan mengalami perkembangan metoda penelitian yang sangat signifikan. Radionuklida natural atau yang dikenal dengan istilah NORM, atau Naturally Occurring Radioactive Material (NORM) didefinisikan sebagai bahan yang mengandung radionuklida primordial atau unsur radioaktif yang terjadi alami seperti radium, thorium, potasium dan produk luruhan radioaktif yang tidak berubah walalupun adanya aktifitas manusia.

TENORM adalah Technologically Enhanced Naturally Occurring Radioactive Material yang didefinisikan sebagai unsur radioaktif yang terkonsentrasi atau terekspos ke lingkungan sebagai akibat aktifitas manusia seperti pabrik, pertambangan ataupun pengolahan air. Technologically enhanced (Secara teknologi ditingkatkan) berarti bahwa sifat radiologi, fisik, dan kimia dari bahan radioaktif telah terkonsentrasi atau telah berubah oleh suatu proses, sehingga dapat meningkatkan potensi paparan radiasi ke manusia dan/atau lingkungan. ${ }^{12}$ Penelitian mengenai konsentrasi radionuklida NORM dan TENORMdunia internasionalsudah banyak diteliti. Penelitian yang dilakukan di Pesisir Arab Saudi untuk pengukuran tingkat radioaktivitas dari ${ }^{238} \mathrm{U},{ }^{232} \mathrm{Th}$ dan ${ }^{40} \mathrm{~K}^{(13)}$ dan di pesisir timur Tamilnadu, India untuk radionuklida ${ }^{238} \mathrm{U},{ }^{232} \mathrm{Th}$ dan ${ }^{40} \mathrm{~K} .{ }^{14}$ 
Pulau Bengkalis terletak di Selat Malaka, merupakan selat yang diapit oleh Pulau Sumatera, Malaysia dan Singapura dan merupakan wilayah perairan yang strategis untuk ketiga negara karena merupakan jalur pelayaran internasional dari Eropa keTimur Tengah dan Timur Jauh. Perairan ini berpotensi mengalami pencemaran laut dari kapal kapal yang melintasi. Seperti yang terjadi pada tahun 1975, terjadinya tumpahan minyak sebanyak 7.300 ton oleh kapal tanker Showa Maru, yang membawa minyak mentah dari Teluk Persia menuju Jepang karena kandas di Selat Malaka. ${ }^{15}$

Selain hal itu tersebut, Selat Malaka mengalami pendangkalan karena tingginya proses sedimentasi dari sungai sungai sungai yang bermuara ke selat tersebut dengan membawa material sedimen dan suspensi ${ }^{(16)}$ termasuk di dalamnya membawa material radionuklida yang dihasilkan oleh industri industri yang menggunakan bahan dari alam. Sedimentasi yang membawa material batuan dan tanah, juga membawa bahan lain seperti bahan radioanuklida natural yang dikenal dengan NORM.Aktivitas yang berhubungan dengan peningkatan kadar NORM yang tidak dikendalikan dapat berpotensi mencemari lingkungan dan menimbulkan resiko untuk kesehatan manusia. ${ }^{12}$

Radionuklida natural, seperti ${ }^{226} \mathrm{Ra}$, mempunyai resiko paparan lebih tinggi dalam jangka waktu lama, mengakibatkan efek berbahaya termasuk anemia, katarak, kanker (terutama kanker tulang), dan kematian. Beberapa dari efek ini mungkin membutuhkan waktu bertahun-tahun untuk berkembang dan sebagian besar disebabkan oleh radiasi gamma yang dipancarkan oleh radium. ${ }^{17}$

Radionuklida natural lain seperti thorium juga telah dibanyak diteliti. Pekerja yang bekerja dengan thorium dan terhirup debunya, dapat menyebabkan peningkatan kemungkinan penyakit paru-paru dan kanker paru-paru atau pancreas bertahun-tahun setelah terpapar. Penyakit hati dan efek pada darah juga ditemukan pada orang yang disuntik dengan thorium. Karena thorium bersifat radioaktif dan dapat disimpan dalam tulang untuk waktu yang lama, kanker tulang juga merupakan masalah potensial bagi orang yang terpapar thorium. ${ }^{18}$

Radionuklida ${ }^{232} \mathrm{Th}$ dan ${ }^{226} \mathrm{Ra}$, termasuk anak luruhnya serta ${ }^{40} \mathrm{~K}$ yang merupakan radionuklida utama ditemukan di alam, dimana aktivitasnya sangat bervariasi tergantung pada lokasi, jenis tanah atau komposisi sedimen. Mayoritas (95\%) dari laju dosis gamma eksternal di atas tanah yang khas muncul dari radionuklida primordial yang diinkorporasikan dalam tanah Selain itu, tanah bertindak sebagai sumber transfer radionuklida ke tanaman dan hewan, sehingga dijadikan indikator dasar dari status radiologis lingkungan pada suatu wilayah. ${ }^{19}$

Banyak penelitian yang telah dilakukan di seluruh dunia untuk menentukan status radiologis suatu wilayah dengan mengetahui aktivitas dari radionuklida di tanahdansedimen. ${ }^{19-22}$ Beberapa penelitian di Indonesia dalam memperkirakan laju dosis dari lingkungan ke biota juga dilakukan menggunakan program ERICA Tools. ${ }^{23}$ Penelitian untuk menentukan laju dosis radionuklida natural juga banyak dilakukan, antara lain yang dilakukan diwilyah Ierissos Gulf, North Aegean Sea, Greece, dengan menggunakan ERICA Tools sebagai perangkat lunaknya.

Penelitian mengenai dampak radiologi dari radionuklida natural dari sedimen menggunakan indeks bahaya eksternal juga dilakukan di wilayah di Pahang $^{19}$ dan Semenanjung Utara ${ }^{20}$ Malaysia, Teluk Saudi Arabia ${ }^{21}$ dan di sekitar pabrik desalinasi air Arab Saudi Timur. ${ }^{22}$

Penelitian ini dilakukan untuk memberikan informasi dasar mengenai tingkat radio aktivitas atau status radiologis di lingkungan perairan laut di Pesisir Pulu Bengkalis. Penelitian ini juga melakukan penilaian dampak bahaya radiologis terhadap lingkungan dengan mengevaluasi indeks bahaya radiasi dari kontaminan lingkungan dari kegiatan nuklir terhadap manusia.

\section{MATERI DAN METODE}

Penelitian ini adalah metode deskriptif, yaitu suatu metode untuk mengadakan pemeriksaan dan melakukan pengukuran gejala empiris yang terjadi di lingkungan perairan laut.

\section{Pengambilan dan Analisis Sampel Sedimen}

Metode pengambilan sampel pada penelitian ini menggunakan metode purposive sampling yaitu suatu penentuan pengambilan sampel sedimen dengan memepertimbangkan hal hal terkait.

Pengambilan sampel sedimen dilakukan pada beberapa tempat di pesisir pantai Pulau Bengkalis menggunakan sediment grabd engan metoda yang telah dimodifikasi. Modifikasi dilakukan pada bentuk sediment grab dan peralatan penunjangnya dengan tidak mempengaruhi fungsi dari alat tersebut. Titik titik pengambilan sampel dapat dilihat pada Gambar Nomor 1 . 


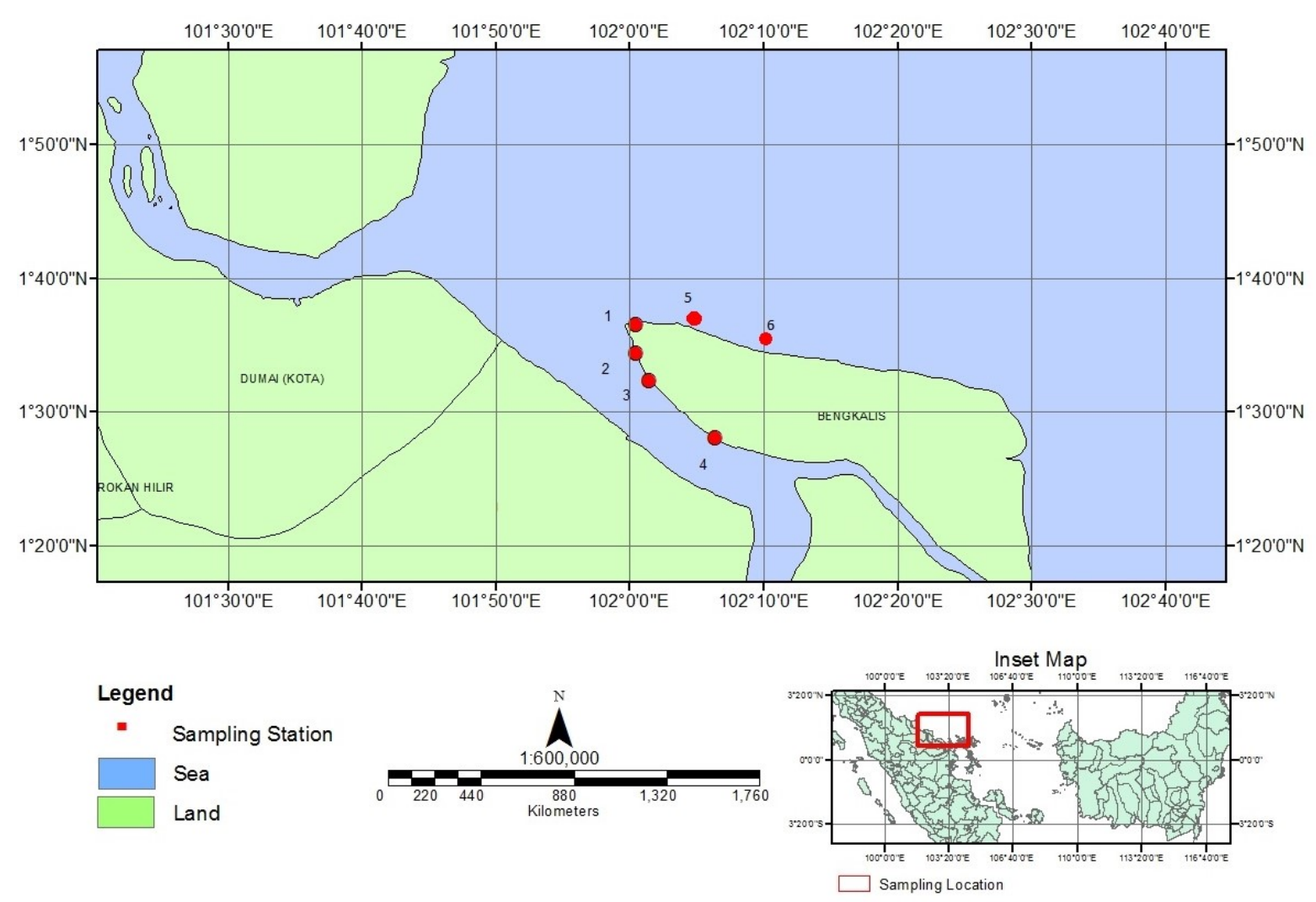

Gambar 1. Titik pengambilan sampel sedimen

Sedimen kemudian dikeringkan menggunakan oven dan dihaluskan sehingga melewati saringan ukuran 50 mikron. Sebanyak 1.000 gram sedimen kering dicacah menggunakan spektrometer gama selama 3 hari. Spektrometri gama yang digunakan dilengkapi dengan perangkat lunak Genie-2000 yang terintegrasi dengan detektor gama coaxial HPGE dengan efisiensi pencacahan 20-25\%. Metoda pencacahan termasuk kalibrasi energi dan efisiensi detektor. Aktivitas ${ }^{226} \mathrm{Ra}$ ditentukan berdasarkan emisi sinar gamma ${ }^{214} \mathrm{~Pb}$ dan ${ }^{214} \mathrm{Bi}$. Aktivtias ${ }^{232} \mathrm{Th}$ ditentukan berdasarkan emisi ${ }^{212} \mathrm{~Pb}$ dan ${ }^{228} \mathrm{Ac}$ dan ${ }^{40} \mathrm{~K}$ ditentukan dari emisi pada $1461,8 \mathrm{keV}$. Konsentrasi aktivitas ${ }^{226} \mathrm{Ra}$ dan ${ }^{232} \mathrm{Th}$ dihitung dari nilai aktivitas rata-rata anak luruhnya tersebut ${ }^{(19)}$. Hasil analisis akan digunakan untuk menghitung dampak radiologis di lingkungan.

\section{Penentuan Parameter Dampak Radiologis}

Dampak radiologis pada lingkungan laut yang diakibatkan oleh radionuklida alami dapat dinilai dengan menggunakan nilai aktivitas radium ekuivalen dan indeks bahaya eksternal (external hazard index, $\mathrm{H}_{\mathrm{ex}}$ ) untuk ${ }^{226} \mathrm{Ra},{ }^{232} \mathrm{Th}$ dan ${ }^{40} \mathrm{~K}$. Hasil analisis tersebut akan digunakan untuk menghitung dampak radiologis di lingkungan. Aktivitas radium ekuivalen dan indeks bahaya eksternal (external hazard index, $\mathrm{H}_{\mathrm{ex}}$ ) diperoleh dengan mengunakan persamaan berikut ini $^{(20)}$ :

$$
\begin{aligned}
& R a_{e q}=A_{R a}+1,43 A_{T h}+0,077 A_{K} \\
& H_{e x}=\frac{A_{R a}}{370}+\frac{A_{T h}}{259}+\frac{A_{K}}{4.810}
\end{aligned}
$$

Dimana nilai $\mathrm{A}_{\mathrm{Ra}}, \mathrm{A}_{\mathrm{Th}}$ dan $\mathrm{A}_{\mathrm{K}}$ adalah aktivitas dari ${ }^{226} \mathrm{Ra},{ }^{232} \mathrm{Th}$ dan ${ }^{40} \mathrm{~K}$.

Laju dosis eksternal (D, nanogray/jam), dengan asumsi berjarak $1 \mathrm{~m}$ diatas permukaan sedimen, diformulasikan menggunakan persamaan:

$D=A X C_{F}$

Dimana nilai A merupakan aktivitas radionuklida $(\mathrm{Bq} / \mathrm{kg})$ dan $\mathrm{CF}$ adalah faktor koreksi laju dosis (nanogray $/ \mathrm{jam} / \mathrm{Bq} / \mathrm{kg}$ ). Faktor koreksi untuk laju dosis adalah 0,$029 ; 0,46$ dan 0,30 untuk masing masing series ${ }^{40} \mathrm{~K},{ }^{232}$ Th dan series ${ }^{238} \mathrm{U}$.

ICRP (1990) dan OECD (1979) menetapkan bahwa $\mathrm{Ra}_{\mathrm{eq}}$ tidak boleh melebihi $370 \mathrm{~Bq} / \mathrm{kg}$ dan nilai Hex tidak melebihi per satuannya. Jika tidak, dosis pajanan terhadap populasi akan melebihi batas yang dapat diterima. ${ }^{19-22}$

\section{HASIL DAN PEMBAHASAN}

Pengambilan sampel sedimen dilakukan pada beberapa titik di pesisir Pantai Pulau Bengkalis pada bulan Mei 2015. Sampel sedimen yang dikumpulkan rata rata mengandung organik yang tinggi ${ }^{16}$,yang mencirikan tingginya proses sedimentasi yang terjadi di sepanjang pesisir pantai. Penelitian yang dilakukan 
pada delta Sungai Rupat, yang berdekatan dengan pulau Bengkalis tahun 2013, menemukan bahwa sedimentasi tertinggi terletak di tengah perairan sehingga perairan tengah laut Selat Rupat sehingga perlu dilakukan pengerukan.

Selain itu, arus dari Selat Malaka dan arus dari Selat Bengkalis yang membawa material diduga dapat mengakibatkan pengendapan pada titik sampling ini yang memiliki kedalaman 16,2 meter. ${ }^{16}$ Ini sesuai dengan penelitian yang dilakukan pada tahun 1998 yang mengemukakan bahwa pertemuan dua massa air mengakibatkan material terdeposisi. ${ }^{24}$ Dalam penelitian tersebut juga menjelaskan hubungan antara pola arus dengan beberapa bagian pantai perairan Selat Rupat yang mengalami abrasi. Saat air pasang, arus merambat dari utara menuju selatan dan membelok ke timur dan bergabung kembali dengan arus di Selat Malaka menuju ke tenggara. Sebaliknya pada saat surut, arus akan bergerak dari arah timur menuju barat dan membelok ke utara dan ke luar di Selat Malaka. Sebaran batuan sedimen di Selat Rupat, persentase yang paling tinggi terdapat ditengah perairan Sungai Dumai, diduga adanya perpindahan batuan sedimen dari aliran sungai yang menumpuk di perairan Selat Rupat.

Hasil penelitianini, didapatkan bahwa nilai aktivitas ${ }^{226} \mathrm{Ra}$ terdapat pada rentang nilai $25,01 \mathrm{~Bq} / \mathrm{kg}$ sampai dengan $109,62 \mathrm{~Bq} / \mathrm{kg}$. Untuk ${ }^{212} \mathrm{~Pb}$ dan ${ }^{214} \mathrm{~Pb}$ berkisar antara $16,91 \mathrm{~Bq} / \mathrm{kg}$ sampai dengan 51,96 $\mathrm{Bq} / \mathrm{kg}$ dan 7,02 Bq/kg sampai dengan 45,97 Bq/kg. Untuk radionuklida ${ }^{214} \mathrm{Bi}$ berkisar pada rentang $6,14-$ $68,47 \mathrm{~Bq} / \mathrm{kg}$, sedangkan untuk ${ }^{228} \mathrm{Ac}$ pada rentang
$13,57-52,21 \mathrm{~Bq} / \mathrm{kg}$. Radionuklida ${ }^{40} \mathrm{~K}$, mempunyai rentang aktivitas yang jauh lebih tinggi dibandingkan dengan radionuklida yang lain, yaitu berkisar antara 99,39 Bq/kg sampai dengan 255,93 Bq/ kg.

Di dunia internasional, penelitian mengenai konsentrasi radionuklida NORM dan TENORM juga mendapat perhatian tinggi. Penelitian yang dilakukan di Pesisir Arab Saudi melaporkan bahwa tingkat radioaktivitas dari ${ }^{238} \mathrm{U},{ }^{232} \mathrm{Th}$ dan ${ }^{40} \mathrm{~K}$ yang dianalisis menggunakan inductively coupled plasma - mass spectrometry (ICP-MS), ${ }^{13}$ dan dilakukan juga di pesisir timur Tamilnadu, India. ${ }^{14}$ Dibandingkan dengan hasil pada penelitian ini, aktivitas ${ }^{40} \mathrm{~K}$ di Pesisir Arab Saudi dan pesisir Tamilnadu, India jauh lebih besar.

Tetapi tetap memerlukan perhatian yang besar dalam pengelolaan lingkungan sekitar, karena tinggi nya aktivitas ${ }^{40} \mathrm{~K}$ yang terdeteksi berhubungan dengan aktivitas industri atau pertambangan yang melibatkan bahan baku dari kerak bumi. Bahan buangan dari industri dan pertambangan tersebut akan masuk ke badan air dan pada akhirnya membentuk sedimentasi di lepas pantai yang mempunyai arus lemah. Penelitian serupa yang dilakukan di perairan laut sebelah utara Malaysia, untuk penentuan aktivitas ${ }^{40} \mathrm{~K}$ dan ${ }^{226}$ Ra pada sampel sedimen ${ }^{20}$.

Data aktivitas dari masing masing radionuklida pada setiap titik pengambilan sampel di pesisir Pulau Bengkalis dapat dilihat pada Tabel 1, dimana pembahasan radionuklida akan dibagi berdasarkan deret peluruhan dari induk luruhnya.

Tabel 1. Data radionuklida natural di pesisir pantai Pulau Bengkalis

\begin{tabular}{|c|c|c|c|c|c|c|c|}
\hline \multirow{2}{*}{ KodeSampel } & \multirow[t]{2}{*}{ Koordinat } & \multicolumn{6}{|c|}{ Aktivitas (Bq/kg) } \\
\hline & & ${ }^{226} \mathbf{R a}$ & ${ }^{212} \mathrm{~Pb}$ & ${ }^{214} \mathrm{~Pb}$ & ${ }^{214} \mathrm{Bi}$ & ${ }^{228} \mathrm{Ac}$ & ${ }^{40} \mathrm{Kv}$ \\
\hline Bengkalis 1 & $\begin{array}{c}102.095^{\circ} \mathrm{BT} \\
1.463^{\circ} \mathrm{LU}\end{array}$ & $101,19 \pm 10,1$ & $51,96 \pm 7.2$ & $18,89 \pm 4,3$ & $18,55 \pm 4,3$ & $28,83 \pm 5,4$ & $238,7 \pm 15,4$ \\
\hline Bengkalis 2 & $\begin{array}{c}102.033^{\circ} \mathrm{BT} \\
1.524^{\circ} \mathrm{LU}\end{array}$ & $25,01 \pm 5,0$ & $16,91 \pm 4,1$ & $12,48 \pm 3,5$ & $12,36 \pm 3,5$ & $15,14 \pm 3,9$ & $126,56 \pm 11,2$ \\
\hline Bengkalis 3 & $\begin{array}{c}102.003^{\circ} \mathrm{BT} \\
1.575^{\circ} \mathrm{LU}\end{array}$ & $29,46 \pm 5,3$ & $22,77 \pm 3,2$ & $7,02 \pm 0,8$ & $6,14 \pm 0,74$ & $13,57 \pm 1,6$ & $99,39 \pm 17,5$ \\
\hline Bengkalis 4 & $\begin{array}{c}102.019^{\circ} \mathrm{BT} \\
1.617^{\circ} \mathrm{LU}\end{array}$ & $25,50 \pm 5,0$ & $29,51 \pm 5,4$ & $45,97 \pm 6,8$ & $28,72 \pm 5,4$ & $21,65 \pm 4,6$ & $225,93 \pm 16,0$ \\
\hline Bengkalis 5 & $\begin{array}{c}102.103^{\circ} \mathrm{BT} \\
1.600^{\circ} \mathrm{LU}\end{array}$ & $47,93 \pm 6,9$ & $47,39 \pm 6,9$ & $43,33 \pm 6,6$ & $68,47 \pm 8,3$ & $52,21 \pm 7,2$ & $184,39 \pm 13,6$ \\
\hline Bengkalis 6 & $\begin{array}{c}102.181^{\circ} \mathrm{BT} \\
1.579^{\circ} \mathrm{LU}\end{array}$ & $109,62 \pm 10,5$ & $19,49 \pm 4,4$ & $28,54 \pm 5,3$ & $64,89 \pm 8,1$ & $48,59 \pm 6,9$ & $207,96 \pm 14,4$ \\
\hline
\end{tabular}

Data primer

\section{Deret Uranium $238\left({ }^{226} \mathrm{R},{ }^{214} \mathrm{~Pb}\right.$ dan $\left.{ }^{214} \mathrm{Bi}\right)$}

Radionuklida ${ }^{226} \mathrm{R},{ }^{214} \mathrm{~Pb}$ dan ${ }^{214} \mathrm{Bi}$ merupakan anak luruh dari deret uranium dengan uranium 238 (umur paro 4,5 milyar tahun) sebagai induk. Deret uranium 238 ini juga dikenal sebagai radium series. Deret ini dimulai dengan uranium -238 yang terjadi secara alami, mencakup unsur-unsur sebagai berikut: astatin, bismut, timbal, polonium, protaktinium, radium, radon, thalium dan thorium. Semua ada, setidaknya secara sementara, dalam setiap sampel yang mengandung uranium alam, baik logam, senyawa, atau mineral. Deret ini berakhir dengan lead-206. ${ }^{12}$

Hasilpenelitian ini, didapatkan rentang aktivitas ${ }^{226} \mathrm{Ra}$ adalah dari $25,01 \mathrm{~Bq} / \mathrm{kg}$ sampai dengan 109,62 $\mathrm{Bq} / \mathrm{kg}$ dengan rata rata sekitar $56,45 \mathrm{~Bq} / \mathrm{kg}$. Data 
penelitian ini komparabel apabila dibandingkan dengan nilai aktivtas ${ }^{226} \mathrm{Ra}$ di pesisir utara Semenanjung Malaysia,yaitu sebesar $51 \mathrm{~Bq} / \mathrm{kg}^{20}$, dan di pesisir Pulau Xiamen, China yaitu sebesar 7,9 sampai dengan $25,7 \mathrm{~Bq} / \mathrm{kg}^{(25)}$. Penelitian serupa yang dilakukan di barat laut Teluk Kuwait mendapatkan aktivitas ${ }^{226} \mathrm{Ra}$ yang lebih rendah dari hasil penelitian ini, yaitu berkisar antara $17,3-23,1 \mathrm{~Bq} / \mathrm{kg}^{(26,27)}$.

Radionuklida ${ }^{214} \mathrm{~Pb}$ dan ${ }^{214} \mathrm{Bi}$ yang mempunyai waktu paruh yang jauh lebih pendek dibandingkan dengan ${ }^{226} \mathrm{Ra}$, terukur pada penelitian ini pada rentang aktivitas antara 7,02 - 45,97 Bq/kg dan 6,14-68,47 $\mathrm{Bq} / \mathrm{kg}$ dengan nilai rata rata sekitar 26,04 dan 33,19 $\mathrm{Bq} / \mathrm{kg}$. Karena waktu paruh yang pendek dari kedua radionuklida pada deret uranium238 ini, maka radionuklida ${ }^{214} \mathrm{~Pb}$ akan meluruh menjadi ${ }^{214} \mathrm{Bi}$ yang kemudian meluruh menjadi ${ }^{214} \mathrm{Po}$ sebagai radionuklida antara dengan mencarkan sinar beta atau meluruh menjadi ${ }^{210} \mathrm{Ti}$ dengan memancarkan partikel alfa. ${ }^{28}$

\section{Deret Thorium $232\left({ }^{228} \mathrm{Ac}\right.$ dan $\left.{ }^{212} \mathrm{~Pb}\right)$}

Radionuklida ${ }^{228} \mathrm{Ac}$ dan ${ }^{212} \mathrm{~Pb}$ termasuk dalam deret thorium 232 yang terjadi secara alami, mencakup unsur-unsur aktinium, bismuth, timbal, polonium, radium dan radon. Semua unsur terdapat dalam setiap sampel yang mengandung thorium alam, baik logam, senyawa, atau mineral. Aktivitas ${ }^{228} \mathrm{Ac}$ dan ${ }^{212} \mathrm{~Pb}$ yang terdeteksi pada sampel sedimen di pesisir Pulau Bengkalis ini berkisar antara 13,57 $52,21 \mathrm{~Bq} / \mathrm{kg}$ dengan rata rata sekitar $30,00 \mathrm{~Bq} / \mathrm{kg}$. Aktivitas ${ }^{212} \mathrm{~Pb}$ terukur antara $16,91 \mathrm{~Bq} / \mathrm{kg}$ sampai dengan $51,96 \mathrm{KBq} / \mathrm{kg}$ dengan rata rata sejumlah 31,34 $\mathrm{Bq} / \mathrm{kg}$.

Penelitian pada di pesisir Pulau Xiamen, China melaporkan ${ }^{232} \mathrm{Th}$ dalam bentuk induk luruhnya terukur sebesar $10,9 \mathrm{~Bq} / \mathrm{kg} .{ }^{25}$ Penelitian yang dilakukan di Pesisir Arab Saudi tingkat radioaktivitas ${ }^{232} \mathrm{Th}$ sebesar 22,5 Bq/kg dan di pesisir timur Tamilnadu, India ditemukan konsentrasi rata rata ${ }^{232} \mathrm{Th}$ sebesar $14,29 \mathrm{~Bq} / \mathrm{kg} .{ }^{14}$ Penelitian di Thailand ditemukan nilai aktivitas ${ }^{232} \mathrm{Th}$ di pesisir barat sebesar
$23,5 \mathrm{~Bq} / \mathrm{kg}$ dan di pesisir sebelah timur sebesar 18,6 $\mathrm{Bq} / \mathrm{kg}^{(29)}$.

\section{Nuklida ${ }^{40} \mathbf{K}$}

Nuklida ${ }^{40} \mathrm{~K}$ merupakan isotop radioaktif natural dari elemen umum kalium (potasium) mewakili sekitar 2,4\% berat kerak bumi). Waktu paruh ${ }^{40} \mathrm{~K}$ adalah $1,248 \times 10^{9}$ tahun. Memiliki kelimpahan persen atom $0,0117 \%$. $\quad\left({ }^{39} \mathrm{~K}\right.$ sebanyak $93,1 \%$ dan ${ }^{41} \mathrm{~K}$ sebanyak 6,88\%, dan keduanya stabil). Aktivitas ${ }^{40} \mathrm{~K}$ yang terdapat pada sedimen pesisir Pulau Bengkalis dari hasil penelitian ini berada pada rentang 99,39 $255,93 \mathrm{~Bq} / \mathrm{kg}$ dengan rata rata sebesar $185,49 \mathrm{~Bq} / \mathrm{kg}$.

Penelitian yang dilakukan di pesisir Barat Thailand, aktivitas ${ }^{40} \mathrm{~K}$ terukur sebesar $10,7-654,3$ $\mathrm{Bq} / \mathrm{kg}$ dan di pesisir sebelah timur Thailand sebesar 182,4 - 559,7 Bq/ $\mathrm{kg}^{(29)}$, sedangkan di pesisir Pulau Xiamen, China sebesar $396,4 \mathrm{~Bq} / \mathrm{kg}^{(25)}$ dan di pesisir timur Tamilnadu, India sebesar 360,23 Bq/ $\mathrm{kg}^{(14)}$. Dibandingkan dengan beberapa hasil penelitian ini, aktivitas ${ }^{40} \mathrm{~K}$ yang terukur di pesisir Pulau Bengkalis berada pada rentang yang sama.

Aktivitas ${ }^{40} \mathrm{~K}$ yang terukur dilingkungan berhubungan dengan sumber kalium yang terdapat di daerah sekitar. Nuklida ${ }^{40} \mathrm{~K}$ adalah sumber radioaktivitas alami terbesar pada hewan termasuk manusia. Tubuh manusia yang mempunyai $70 \mathrm{~kg}$ mengandung sekitar 140 gram potassium didalamnya.

\section{Dampak Bahaya Radiologis dari Radionuklida Natural terhadap Lingkungan Laut}

Penghitungan indeks radiologis pesisir Pulau Bengkalis yang didapatkan dari penghitungan nilai aktivitas ekuivalen radium $\left(\mathrm{Ra}_{\mathrm{eq}}\right)$ berkisar dari 82,61 $\mathrm{Bq} / \mathrm{kg}$ sampai dengan $138 \mathrm{~Bq} / \mathrm{kg}$ dan tidak melebihi nilai yang ditetapkan oleh ICRP (1990) dan OEC ${ }^{20}$ yaitu sebesar $370 \mathrm{~Bq} / \mathrm{kg}$. sedangkan nilai indeks bahaya eksternal $\left(\mathrm{H}_{\mathrm{ex}}\right)$ yang dihitung dari hasil penelitian ini didapatkan nilai rata rata sebesar 0,31 , masih di bawah angka1. Dengan demikian dapat dikatakan bahwa dosis yang diterima oleh lingkungan masih di bawah limit yang ditetapkan.

Tabel 2. nilai aktivitas ekuivalen radium $\left(\mathrm{Ra}_{\mathrm{eq}}\right)$ dan indeks bahaya eksternal $\left(\mathrm{H}_{\mathrm{ex}}\right)$ Perairan laut Bengkalis

\begin{tabular}{ccccccc}
\hline \multirow{2}{*}{ No } & \multirow{2}{*}{ okkasi } & \multicolumn{3}{c}{ Aktivitas (Bq/kg) } & \multicolumn{2}{c}{ Indeks Radiologi } \\
\cline { 3 - 6 } & & ${ }^{\mathbf{4 0}} \mathbf{K}$ & ${ }^{\mathbf{2 3 2}} \mathbf{T h}$ & ${ }^{\mathbf{2 2 6}} \mathbf{R a}$ & $\mathbf{R a}_{\mathbf{e q}}$ & $\mathbf{H}_{\mathbf{e x}}$ \\
\hline 1 & Bengkalis 1 & $238,70 \pm 15,45$ & $40,40 \pm 8,99$ & $46,21 \pm 11,7$ & $122,35 \pm 17,87$ & $0,33 \pm 0,12$ \\
2 & Bengkalis 2 & $126,56 \pm 11,25$ & $16,03 \pm 5,66$ & $16,62 \pm 7,06$ & $49,28 \pm 12,59$ & $0,13 \pm 0.08$ \\
3 & Bengkalis 3 & $99,39 \pm 17,46$ & $18,17 \pm 3,59$ & $14,21 \pm 5,5$ & $47,84 \pm 17,83$ & $0,13 \pm 0.09$ \\
4 & Bengkalis 4 & $255,93 \pm 16,00$ & $25,58 \pm 7,15$ & $33,40 \pm 10,01$ & $89,68 \pm 17,52$ & $0,24 \pm 0.10$ \\
5 & Bengkalis 5 & $184,39 \pm 13,58$ & $49,80 \pm 9,98$ & $53,24 \pm 12,64$ & $138,66 \pm 16,85$ & $0,37 \pm 0.12$ \\
6 & Bengkalis 6 & $207,96 \pm 14,42$ & $34,04 \pm 8,25$ & $67,68 \pm 14,25$ & $132,37 \pm 16,61$ & $0,36 \pm 0,12$ \\
\hline
\end{tabular}

Hasil perhitungan dari data primer

Efek radiologis dari paparan zat radioaktif di atas ambang batas tertentu dapat berpotensi mengancam kehidupan, sehingga tidak dapat diabaikan. Adanya unsur radioaktif dalam jumlah tertentu dalam sedimen dari daerah penelitian, akan memberikan indikasi perlu atau tidaknya suatu tindakan pencegahan diambil. Secara pragmatis penentuan laju dosis terhadap hewan dan tumbuhan, sebagai alat penilaian batas dosis, menggunakan koefisien konversi dosis atau faktor konversi dosis dalam satuan $\mathrm{mGy} / \mathrm{jam} / \mathrm{Bq} / \mathrm{kg}$ masa tubuh. Suatu organisme diasumsikan memperoleh dosis internal lebih besar dibandingkan dengan perkiraan dosis eksternal dari senyawa radioaktif, yang 
didistribusikan secara homogen ke seluruh tubuh dan medianya ${ }^{30}$ tetapi penghitungan dosis eksternal perlu dilakukan. Penelitian ini juga melakukan perhitungan laju dosis yang diserap dari radionuklida natural pada wilayah Bengkalis. Nilai laju dosis eksternal dapat dilihat pada Tabel 3 Berikut ini.

Tabel 3. Laju dosis eksternal pada $1 \mathrm{~m}$ diatas permukaan sedimen yang mengandung radionuklida natural

\begin{tabular}{|c|c|c|c|c|c|}
\hline \multirow[t]{2}{*}{ No } & \multirow[t]{2}{*}{ Lokasi } & \multicolumn{4}{|c|}{$\begin{array}{c}\text { Laju dosis pajanan eksternal } \\
\text { D }(\mathrm{nGy} / \mathrm{h})\end{array}$} \\
\hline & & ${ }^{40} \mathrm{~K}$ & ${ }^{232} \mathrm{Th}$ & ${ }^{226} \mathrm{Ra}$ & Total \\
\hline 1 & Bengkalis 1 & $6,92 \pm 0,57$ & $18,58 \pm 4,24$ & $13,86 \pm 3,60$ & $39,37 \pm 5,59$ \\
\hline 2 & Bengkalis 2 & $3,67 \pm 0,37$ & $7,37 \pm 2,63$ & $4,99 \pm 2,13$ & $26,03 \pm 3,41$ \\
\hline 3 & Bengkalis 3 & $2,88 \pm 0,53$ & $8,36 \pm 1,70$ & $4,26 \pm 1,66$ & $42,22 \pm 2,44$ \\
\hline 4 & Bengkalis 4 & $7,42 \pm 0,59$ & $11,77 \pm 3,34$ & $10,02 \pm 3,04$ & $29,21 \pm 4,56$ \\
\hline 5 & Bengkalis 5 & $5,35 \pm 0,48$ & $22,91 \pm 4,73$ & $15,97 \pm 3,87$ & $44,23 \pm 6,13$ \\
\hline 6 & Bengkalis 6 & $6,03 \pm 0,52$ & $15,66 \pm 3,88$ & $20,31 \pm 4,39$ & $41.99 \pm 5,88$ \\
\hline
\end{tabular}

Hasil perhitungan dari data primer

Hasilperhitungan lajudosis eksternal yang dihasilkan dari nuklida natural dari wilayah penelitian ini berkisar dari 26,03nGy/h sampai dengan 44,23 $\mathrm{nGy} / \mathrm{h}$ dengan nilai rata rata $37,175 \mathrm{nGy} / \mathrm{h}$. Laju dosis eksternal dari penelitian ini lebih tinggi dibandingkan dengan hasil penelitian serupa yang dilakukan di sepanjang pesisir Teluk Arab Saudi, dengan kisaran antara 9,2 hingga $28,0 \mathrm{nGy} / \mathrm{h}$, dengan rata-rata 16,1 $\mathrm{nGy} / \mathrm{h}^{21}$, tetapi lebih rendah apabila dibandingkan dengan nilai rata-rata dunia yaitu sebesar 55,0 - 57,0 $\mathrm{nGy} / \mathrm{h}^{20,21}$

\section{SIMPULAN}

Aktivitas radionuklida natural di pesisir Pulau Bengkalis untuk radionuklida ${ }^{226} \mathrm{Ra},{ }^{212} \mathrm{~Pb},{ }^{214} \mathrm{~Pb}$, ${ }^{214} \mathrm{Bi},{ }^{228} \mathrm{Ac}$ dan ${ }^{40} \mathrm{~K}$ didapatkan nilai rata-ratanya berturut turut 56,$45 ; 31.34 ; 26,04 ; 33,19 ; 30,00$ dan $185,49 \mathrm{~Bq} / \mathrm{kg}$. Nilai aktivitas ini dibandingkan dengan aktivitas yang terukur pada beberapa negara mempunyai kisaran nilai yang berdekatan.

Penilaian dampak bahaya radiologis terhadap radionuklida natural pada sampel sedimen dipesisir Pulau Bengkalis menggunakan nilai aktivitas ekuivalen radium $\left(\mathrm{Ra}_{\mathrm{eq}}\right)$ dengan nilai berkisar dari $82,61 \mathrm{~Bq} / \mathrm{kg}$ sampai dengan $138 \mathrm{~Bq} / \mathrm{kg}$ dan tidak melebihi nilai yang ditetapkan oleh ICRP (1990) dan OECD yaitu sebesar $370 \mathrm{~Bq} / \mathrm{kg}$. Nilai indeks bahaya eksternal $\left(\mathrm{H}_{\mathrm{ex}}\right)$ didapatkan nilai rata rata masih di bawah 1, yaitu sebesar 0,31. Laju dosis yang diterima dari radionuklida natural pada wilayah Bengkalis rata ratasebesar $37,175 \mathrm{nGy} / \mathrm{h}$, masih di bawah nilai rata rata dunia yaitu sebesar 55,0-57,0 $\mathrm{nGy} / \mathrm{h}$.

Dengan demikian, dapat disimpulkan bahwa parameter radiologis radionuklida natural dalam sedimen di pesisir Pulau Bengkalis berada dalam batas yang dapat diterima. Penapisan radiologis lebih lanjut akan direkomendasikan apabila di area tersebut mempunyai nilai konsentrasi aktivitas tinggi, yang ditujukan untuk memastikan perlindungan terhadap masyarakat di sekitarnya.

\section{DAFTAR PUSTAKA}

1. Ergul AH, Belivermis M, Önder K, Topcuoglu S, Cotuk Y. Natural and arti ficial radionuclide activity concentrations in surface sediments of
Izmit Bay, Turkey J. Environ Radioact. 2013;126:125-32.

2. Carvalho FM de, Lauria D da C, Ribeiro FCA, Fonseca RT, Peres S da S, Martins NSF. Natural and man-made radionuclides in sediments of an inlet in Rio de Janeiro State, Brazil. Mar Pollut Bull. 2016;107(1):269-76.

3. Makmur M, Herlambang M. Sebaran Aktivitas 239, $240 \mathrm{Pu}$ di Sedimen Perairan Arus Lintas Indonesia (ARLINDO) Jalur Sekunder. In: Prosiding Seminar Nasional Teknologi Lingkungan XII. 2015.

4. Ergül HA, Belivermiş M, Kiliç Ö, Topcuoğlu S, Çotuk Y. Natural and artificial radionuclide activity concentrations in surface sediments of Izmit Bay, Turkey. J Environ Radioact. 2013;126:125-32.

5. Suseno H, Prihatiningsih WR. Monitoring 137Cs and 134Cs at marine coasts in Indonesia between 2011 and 2013. Mar Pollut Bull. 2014;88(12):319-24.

6. Suseno H, Wahono IB, Muslim M, Yahya MN. Status of $137 \mathrm{Cs}$ concentrations in sea water at the inlets of the Indonesian Through Flow (ITF). Reg Stud Mar Sci [Internet]. 2017;10:81-5. Available from:

http://dx.doi.org/10.1016/j.rsma.2016.12.008

7. Suseno H, Makmur M, Yahya MN. Present Status of Marine Radioecology in Jakarta Bay. Atom Indones. 2017;44(2):1-5.

8. Makmur M. Inventori Radionuklida Plutonium Dan Americium di Sedimen Pesisir Laut Gresik. J Teknol Pengelolaan Limbah. 2014;17(1):55-61.

9. Makmur M, Yahya MN, Putra DIP. Concentration of Selected Radionuclides in Sediment and Surface Seawater in Belitung Island , Indonesia. In: 2nd International Conference on the Sources, Effect and Risk of Ionizing Radiation. 2016. p. 29-34.

10. Makmur M. Analisis Plutonium di Sedimen Perairan Laut Bangka. In: Seminar Keselamatan Nuklir. 2013.

11. Makmur M. Sebaran Radionuklida 239,240Pu di Air Permukaan Selat Bangka. J Teknol Pengelolaan. 2013;16(399). 
12. US-EPA. Technologically Enhanced Naturally Occurring Radioactive Materials ( TENORM ). https:/www.epa.gov/radiation/technologicallyenhanced-naturally-occurring-radioactivematerials-tenorm. 2016;1-2.

13. Al-Trabulsy HAM, Khater AEM, Habbani FI. Heavy elements concentrations, physiochemical characteristics and natural radionuclides levels along the Saudi coastline of the Gulf of Aqaba. Arab J Chem. 2013;6(2):183-9.

14. Ravisankar R, Chandramohan J, Chandrasekaran A, Prince Prakash Jebakumar J, Vijayalakshmi I, Vijayagopal P, et al. Assessments of radioactivity concentration of natural radionuclides and radiological hazard indices in sediment samples from the East coast of Tamilnadu, India with statistical approach. Mar Pollut Bull. 2015;97(12):419-30.

15. Adi T. Kasus tumpahan minyak Showa Maru [Internet]. 2018. p. 4. Available from: https://www.academia.edu/11839835/

16. Helfinalis. Endapan Sedimen dan Sebaran Suspensi di Perairan Selat Malaka 2001. In: Perairan Indonesia, Oseanografi, Biologi dan Lingkungan. 2002.

17. Agency for Toxic Substances and Disease Registry - U.S. Public Health Service. Toxicological Profile for Radium [Internet]. Agency for Toxic Substances and Disease Registry - U.S. Public Health Service; 1990. Available from: https://www.atsdr.cdc.gov/toxprofiles/tp144.pdf

18. Agency for Toxic Substances and Disease Registry - U.S. Public Health Service, US-EPA. Toxicological Profile for Thorium [Internet]. https://www.atsdr.cdc.gov/toxprofiles/tp147.pdf; 1990. Available from: https://www.atsdr.cdc.gov/toxprofiles/tp147.pdf

19. Gabdo HT, Ramli AT, Saleh MA, Sanusi MS, Garba NN, Aliyu AS. Radiological hazard associated with natural radionuclide concentrations in the northern part of Pahang state Malaysia. Env Earth Sci. 2015;73(10).

20. Muhammad BG, Jaafar MSMS, Rahman AA, Ingawa FA. Determination of radioactive elements and heavy metals in sediments and soil from domestic water sources in northern peninsular Malaysia. Environ Monit Assess. 2012;184(8):5043-9.

21. Al-ghamdi H, Al-muqrin A, El-sharkawy A. Assessment of natural radioactivity and $137 \mathrm{Cs}$ in some coastal areas of the Saudi Arabian gulf. Mar Pollut Bull [Internet]. 2016;104(1-2):1-5. Available from: http://dx.doi.org/10.1016/j.marpolbul.2016.01.05 8

22. Alshahri F. Radioactivity of $226 \mathrm{Ra}, 232 \mathrm{Th}, 40$ $\mathrm{K}$ and $137 \mathrm{Cs}$ in beach sand and sediment near to desalination plant in eastern Saudi Arabia: Assessment of radiological impacts. J King Saud
Univ - Sci [Internet]. 2017;29(2):4-11. Available from:

http://dx.doi.org/10.1016/j.jksus.2016.08.005

23. Prihatiningsih WR, Soedharma D, Suseno H, Zamani NP. Dose Rates Assessment of 137 Cs for Chanos chanos using ERICA Tool. In: 2nd Intl Conference on the Sources, Effects and Risk of Ionizing Radiation (SERIR2). 2016. p. 25-8.

24. Sihombing T, Rifardi. Komposisi sedimen bagian timur Selat Rupat Provinsi Riau. J Perikan dan Kelaut. 2014;19:45-52.

25. Huang $Y$, Lu X, Ding $X$, Feng T. Natural radioactivity level in beach sand along the coast of Xiamen Island, China. Mar Pollut Bull [Internet]. 2015;91(1):357-61. Available from: http://dx.doi.org/10.1016/j.marpolbul.2014.11.04 6

26. Uddin S, Behbehani M. Concentrations of selected radionuclides and their spatial distribution in marine sediments from the northwestern Gulf, Kuwait. Mar Pollut Bull [Internet]. 2018;127(December 2017):73-81. Available from: https://doi.org/10.1016/j.marpolbul.2017.11.052

27. Uddin S, Aba A, Fowler SW, Behbehani M, Ismaeel A, Al-shammari $\mathrm{H}$, et al. Radioactivity in the Kuwait marine environment - Baseline measure- ments and review. 2015;100:651-61.

28. US-EPA. Technologically Enhanced Naturally Occurring Radioactive Materials (TENORM). www.epa.gpv. 2018.

29. Malain D, Regan PH, Bradley DA, Matthews M, Santawamaitre T, Al-Sulaiti HA. Measurement of NORM in Beach sand samples along the Andaman coast of thailand after 2004 tsunami. Nucl Instruments Methods Phys Res. 2010;619(1-3):1-21.

30. Stark K, Goméz-Ros JMJM, Vives i Batlle J, Lindbo Hansen E, Beaugelin-Seiller K, Kapustka LALA, et al. Dose assessment in environmental radiological protection: State of the art and perspectives. J Environ Radioact. 2017;175176:105-14. 